experts were established to help them grow professionally. The 1940s were connected with the Weiscotten Report.

The study covers only a part of aspects of the problem. Concerning the prospects of further research, the plan is to describe the Weiscotten Report that deals with innovative activity in the American medical education from 1934 to 1939.

Key words American medical education, educational reforms, innovations, US medical schools, Flexner Report, Weiscotten Report, science-oriented curriculum, professional scientific literature.

удк 371.3:811.111

\author{
Маріанна Леврінц \\ Закарпатський угорський \\ інститут ім. Ракоці Ференца II \\ ORCID ID 0000-0002-2206-7113
}

DOI 10.24139/2312-5993/2020.01/030-038

\title{
ТРАНСФОРМАЦІЯ КОНЦЕПТУАЛЬНИХ ПОЛОЖЕНЬ СИСТЕМИ ПІДГОТОВКИ ВЧИТЕЛІВ ІНОЗЕМНИХ МОВ У США
}

Метою статті є аналіз трансформацій концептуальних положень у галузі підготовки вчителів іноземних мов у США. Дослідження виконано із застосуванням методів системного аналізу й узагальнення тенденцій розвитку теоретикометодологічних засад срери іншомовної педагогічної освіти. 3’ясовано, що в сучасній науково-світоглядній картині американських освітян на передній план виступили концептуальні ідеї соціалконструктивізму, критичної педагогіки, гуманізму й постпозитивістька епістемологія, оформившись у соціокультурній парадигмі. Основними тенденціями розвитку методологічних підвалин галузі $\epsilon$ перехід від трансмісійної до колаборативної, транзакційної та перетворювальної моделей у вищій освіті; від тренувальної до розвивальної парадигми підготовки вчителівфілологів; відбувається переосмислення ролі студента в прочесі навчальнопрофесійної діяльності. Оновлена концептуальна парадигма характеризується відмовою від ідеї прямолінійності в розбудові наукового знання на користь переосмислення ролі особистості в перетворенні знаннєвої бази, освітнього середовища та соціокультурного контексту.

Ключові слова: система підготовки вчителів іноземних мов, концептуальні положення, трансформація, наукове знання, США.

Постановка проблеми. Інтегрованість американської системи підготовки вчителів іноземних мов обумовлюється загальнонауковими й галузевими концептуальними положеннями, які формують наукову картину світу суб'єктів освітньої системи, визначають хід і закономірності їі розвитку, задають алгоритм і темпи ії життєдіяльності, трансформування. Провідні концептуальні освітні орієнтири покликані впорядковувати множинні ідіосинкретні погляди на фундаментальні проблеми підготовки вчителів, перетворюючи їх на конкретні дидактичні шляхи реалізації в освітньому процесі. Розглянемо сучасні теоретичні положення галузі 
підготовки вчителів-філологів у діалектичній перспективі, абстрагуючи й узагальнюючи основні тенденції розвитку сучасних теорій навчання й учіння. Незважаючи на наявність суперечностей як у концептуалізації основних теоретичних категорій галузі, так і у виділенні дидактичних підходів, детальне вивчення доводить їхню гомогенність, а отже й можливість фіксування їхніх основоположних рис.

Аналіз актуальних досліджень. Вивченню теоретико-методологічних проблем підготовки педагогів у галузі іншомовної освіти США присвячено чимало праць зарубіжних і вітчизняних учених. У роботі ми насамперед спиралися на доробок таких американських дослідників, як БоллД., Браун Д., Джонсон К., Кренделл Дж., Кумарадівелу Б., Фрімен Д. і багато інших. Важливі питання педагогічної й філологічної освіти США порушуються в працях Бідюк Н., Іконнікової М., Кокор М., Кошманової Т., Черній Л., Шандрук С., Шихненко К. та ін. Зауважимо, що наявність певних напрацювань із досліджуваної проблеми уможливлює виділення основних трансформаційних тенденцій у концептуальних положеннях системи підготовки вчителів іноземних мов у США.

Мета статті. Здійснити системний аналіз трансформацій концептуальних положень галузі підготовки вчителів іноземних мов у США.

Методи дослідження. Досягненню означеної мети сприяє використання методів системного аналізу, ретроспекції й узагальнення тенденцій розвитку теоретико-методологічних засад галузі філологопедагогічної іншомовної освіти, а також аналіз практичного досвіду підготовки вчителів іноземних мов у США.

Виклад основного матеріалу. Ключовими категоріями теоретичного фундаменту системи підготовки вчителів іноземних мов (СПВІМ) є учіння й навчання. Загальнопоширеним $€$ визнання провідної ролі вчителя в результативності навчання учнів (Blazar, 2016). Відтак, якість професійнопедагогічної діяльності знаходиться під постійною увагою американської спільноти, вживаються полівекторні й багаторівневі заходи, спрямовані на їі зростання, гарантування якісної освіти всім учням країни без винятку (Закон «Не залишимо жодної дитини без уваги», 2001) представниками федералітету, науково-освітньої спільноти й широкої громадськості, окремими з яких оптимізація програм підготовки вчителів IM (іноземних мов), імплементування системи підзвітності в освітній системі, узагальнення вимог до компетентнісного рівня вчителів у вигляді прийняття освітніх стандартів та ін.

Однак, навчання й учіння не завжди перебувають у стані діалектичної взаємозалежності. Кристалізація означеного усвідомлення серед лав американських науковців ознаменувала перегляд традиційних підходів до витлумачення сутності низки педагогічних явищ. Парадигмальних змін зазнали моделі навчання, особливості педагогічної взаємодії між учасниками освітніх процесів, фокус творчо-пошукових робіт 
тощо. Ґрунтуючись на філософсько-епістемологічних засадах позитивізму й біхевіоризму, які міцно вкорінились у світоглядних позиціях американської освітньої громадськості, у США протягом тривалого часу переважала трансмісійна або процесуально-продуктивна модель навчання. Постулативними для означеної парадигми $€$ знак рівності між навчанням і учінням, де потік навчальної інформації пасивно сприймається учнями. Студент $€$ об'єктом для змістового наповнення й формування в нього основних практичних умінь, а не суб'єкт, який бере активну участь у процесі творчого перетворення зовнішніх і внутрішніх ресурсів на професійно значимі компетентності. Американські дослідники Джонсон К. і Фріман Д. (2001) зазначають, що СПВІМ, базована на трансмісійній моделі, прагнула забезпечити студентів теоретичними галузевими знаннями й елементарними вміннями виконувати професійні обов'язки (Johnson, Freeman, 2001, с. 54-55), уподібнюючи професійне становлення технологічному процесу, кінцевим продуктом якого $\epsilon$ «готовий до використання» педагогічний працівник, укомплектований знаннями й уміннями. Майбутній учитель уважається недостатньо компетентним для прийняття самостійних рішень щодо організації власного навчання (Britzman, 2003, с. 46). Основні навчальні методи ґрунтуються на імітації зразків виконання навчально-професійних завдань, некритичному опрацюванні навчального матеріалу та переказуванні.

Переформатування трансмісійної освітньої моделі розпочинається із виходом на наукову арену теорії когнітивізму, яка акцентує увагу на мисленнєвих процесах, інтелектуальних здібностях, критичному мисленні. Якщо для біхевіористів неосмислене засвоєння й відтворення навчального матеріалу становить основу учіння, то для когнітивістів - це лише перший етап навчання, який надалі передбачає активне мисленнєве перетворення інформації. Відтак, «відтворення» в навчанні переходить в особистісне «перетворення» знаннєвої бази. Поступовий перегляд ролі студента в якості активного учасника освітнього процесу супроводжується рухом у напрямі від учителецентризму до студентоцентризму як головної форми педагогічної взаємодії.

Унаслідок розгляду майбутніх учителів у ролі активних, дієздатних учасників власного професійного становлення й освітнього процесу, змінюється також тематика науково-дослідницьких робіт, головними серед яких стають ментальні процеси, учіння педагога або вчитель у ролі того, хто навчається, рефлексія в навчально-професійній діяльності тощо.

Паралельно у СПВІМ відбувається переорієнтація з тренувальної моделі (teacher training) на розвивальну (teacher development). Тренування в підготовці педагогів розглядається як формування базових теоретикопрактичних азів, які уможливлюють практичне застосування елементарних навичок викладання. У парадигмі освіти або розвитку вчителів розв'язання 
проблеми підготовки педагога здійснюється 3 особистісних позицій: професійне становлення передбачає не тільки оволодіння практичними техніками викладання, але й цілісний розвиток особистості майбутнього вчителя через рефлексивний аналіз навчально-професійної діяльності, критичне опрацювання навчального матеріалу, самоосвіту, самовдосконалення тощо (Richards, Farrel, 2005).

Однак, у гонитві за високими ідеалами поза увагою освітян ризикує опинитися практична підготовленість початкуючого вчителя навчати IM, розвивати іншомовну компетентність учнів, що $\mathrm{i} \epsilon$ його основною функцією. На думку БолД. та ін. (2010), готовність і здатність учителя вправно навчати учнів вимагає ретельної професійної підготовки саме в тренувальному форматі. Розвинені навички викладання не применшують професійного статусу педагога, як стверджують критики тренувального підходу, а навпаки, становлять його фундамент. Професійно-педагогічна діяльність, базована на імпровізуванні, обмежуючись індивідуальним досвідом учителя у формуванні фахової компетентності, нівелює професійність педагогічної праці (Ball, Forzani, 2010, с. 508-509).

3 міркуваннями авторів важко не погодитись, адже власне сутність професії полягає в здатності індивіда виконувати комплекс практичних дій на основі спеціальних знань, які є загальним надбанням професійної групи. Якщо означений компонент спеціальних знань і вмінь відсутній, то й праця вчителя не може належати до розряду професій. Таким чином, СПВІМ повинна вибудовуватися за принципом конвергенції, включаючи як тренувальну, так і розвивальну парадигми, оскільки обидві $\epsilon$ життєдайними для професійного становлення й розвитку вчителя.

Подальші трансформації в концептуалізації проблем підготовки вчителів IM розгортаються на тлі теорій конструктивізму або соціалконструктивізму, сформованих як логічне довершення ідей попередників теорій когнітивізму й гуманізму (Brown, 2000). 3 позицій означених теорій навчання відбувається внаслідок активного особистісного конструювання індивідом знань: інформація, що поступає ззовні, перетворюється індивідом з огляду на наявний попередній досвід, світоглядну картину, віддзеркалюючись від навколишнього середовища. Відтак, студент не $€$ «чистою дошкою», на яку наносять інформацію, а $€$ співавтором професійної знаннєвої бази. У галузі підготовки вчителів уплив конструктивізму спостерігається в оформленні нових моделей, як наприклад, рефлексивної, яка передбачає не лише теоретико-практичне озброєння студента через передачу релевантної інформації, а й глибокий аналіз і осмислення майбутнім учителем педагогічних явищ.

Оновлена візуалізація освітніх проблем через призму конструктивістських концепцій привернула увагу науковців до проблеми учіння вчителя, тобто внутрішньо-особистісних процесів, які відбуваються в 
ході його професійного становлення. До недавнього часу вчитель IM розглядався в ролі споживача психолого-педагогічної та лінгвістичної теорій, однак ігнорування думки практика в розбудові теорії неминуче призводить до однобічного трактування важливих понять галузі. Наразі, роль учителя IM у цьому розрізі зазнала кардинальних змін. Він розглядається не лише як користувач, але й автор психолого-педагогічної теорії. Для прикладу, в літературі плідно розробляються проблеми педагогічного дослідження та дослідження дією (teacher research, action research), присвячених вивченню особливостей залучення вчителів і студентів до творчо-пошукової діяльності (Burns, 2013).

Важливою нинішньою тенденцією в галузі підготовки вчителів IM у США $є$ розвиток концептуальних засад у соціокультурній перспективі. Якщо теоретики біхевіоризму й когнітивізму розглядали навчання як індивідуально зумовлений процес, то соціалконструктивізм зосередився на вивченні впливу соціальних факторів у навчанні (Johnson, Freeman, 2001). Формування професійно-педагогічної компетентності, розвиток професійних знань і вмінь відбувається внаслідок залучення до навчання й викладання за конкретних контекстуальних обставин, що надає їй індивідуального контекстуально-залежного забарвлення. Дидактичними шляхами імплементації ідей соціокультурної парадигми в практику підготовки вчителів IM стали колаборативні форми навчання й викладання, співпраця між учасниками освітніх процесів, як наприклад між викладачами 3ВО і шкільними вчителями тощо.

Однією з незворотних тенденцій, що характеризує сучасний стан концептуального оформлення галузі підготовки вчителів IM, $€$ відмова від догматизму, прескриптивності до більш критичного ставлення до пропонованих теоретичних положень. Майбутнього вчителя закликають розвивати усвідомлення про наявність множинних перспектив, що дають пояснення фундаментальних освітніх феноменів. Відповідно, «модна» теорія не може претендувати на звання панівної та єдино правильної, а лише одним із можливих теоретичних обґрунтувань проблем освіти. У сфері викладання IM означена тенденція набула вигляду «післяметодової ери» та «просвітленого еклектицизму», для яких властивими є заперечення існування ідеального методу навчання IM усіх без винятку учнів (Kumaradivelu, 2012). Сучасний учитель IM $€$ ґрунтовно ознайомленим із навчальними підходами й методами, однак освітній процес вибудовує з урахуванням інтересів і потреб учнівської спільноти й ситуативних обставин.

Помітним віянням у галузі підготовки вчителів IM $є$ сформоване під дією критичної педагогіки усвідомлення того, що вивчення IM не $\epsilon$ нейтральним, незалежним від ширших суспільних процесів і може мати негативні наслідки для соціального стану студентів. Окремим прикладом може слугувати роль англійської мови в умовах лінгвальної глобалізації, 
яка займає провідні позиції в науковій, політико-економічній та інших галузях (Philipson, 1992). Учитель, для якого іноземна мова, що викладається, $€$ рідною, також має привілейований статус порівняно 3 педагогом, який не є носієм мови з народження (Megyes, 2001). Наразі у світлі критичної педагогіки здійснюються спроби освітян налагодити баланс між викладанням IM і підтримкою менш уживаних мов, пошук шляхів розвитку критичного ставлення, осмислення майбутніми вчителями теоретичних засад галузі та ролі IM у соціальному контексті.

Під упливом теорій критичної педагогіки і міжкультурної комунікації в США назріло оновлене бачення ролі вчителя-словесника як медіатора між представниками різних культурних груп або посередника між корінними й новоприбулими членами суспільства. Оскільки США $€$ країною емігрантів, суспільна місія вчителя IM є вкрай важливою, уособлюючи через засвоєння мови перспективи повноцінної соціалізації у «країні можливостей». Результати аналізу трансформацій концептуальних положень системи підготовки вчителів-філологів у США представлено в таблиці 1.

\section{Таблиця 1}

Трансформація концептуальних положень у галузі підготовки вчителів IM у США

\begin{tabular}{|c|c|}
\hline $\begin{array}{l}\text { Трансмісійна модель у навчанні й } \\
\text { підготовці вчителів ІМ. }\end{array}$ & $\begin{array}{l}\text { Колаборативна/транзакційна/ } \\
\text { трансформативна модель. }\end{array}$ \\
\hline $\begin{array}{l}\text { Підготовка вчителя } \text { в } \text { тренувальній } \\
\text { парадигмі. }\end{array}$ & Освіта/розвиток учителя. \\
\hline Біхевіоризм, когнітивізм. & $\begin{array}{l}\text { Конструктивізм, критична педагогіка, } \\
\text { гуманізм. }\end{array}$ \\
\hline $\begin{array}{l}\text { Студент як пасивний сприймач } \\
\text { інформації. }\end{array}$ & $\begin{array}{l}\text { Студент як активний перетворювач } \\
\text { інформації. }\end{array}$ \\
\hline $\begin{array}{l}\text { Студент як об'єкт педагогічного впливу й } \\
\text { освітнього процесу. }\end{array}$ & $\begin{array}{l}\text { Студент як суб'єкт педагогічної взаємодії та } \\
\text { освітнього процесу. }\end{array}$ \\
\hline $\begin{array}{l}\text { Студент/учитель - споживач психолого- } \\
\text { педагогічної, лінгводидактичної та інших } \\
\text { теорій. }\end{array}$ & $\begin{array}{l}\text { Студент/учитель - співавтор психолого- } \\
\text { педагогічної, лінгводидактичної та ін. } \\
\text { теорій. Залучення вчителів до науково- } \\
\text { пошукової діяльності. }\end{array}$ \\
\hline $\begin{array}{l}\text { Сконцентрованість на } \\
\text { майбутнього вчителя. }\end{array}$ & $\begin{array}{l}\text { Акцент на учінні майбутнього вчителя } \\
\text { (яким чином студент навчається викладати } \\
\text { IM). }\end{array}$ \\
\hline $\begin{array}{l}\text { Навчання як індивідуальний процес. } \\
\text { Індивідуальні навчальні форми. }\end{array}$ & $\begin{array}{l}\text { Навчання як соціально зумовлений процес. } \\
\text { Колаборативні/колективні } \\
\text { організації навчання. }\end{array}$ \\
\hline $\begin{array}{l}\text { Техніцизм у підготовці вчителя (вивчення } \\
\text { теоретичних основ, розвиток } \\
\text { елементарних практичних умінь). }\end{array}$ & $\begin{array}{l}\text { Рефлексія в навчально-професійній } \\
\text { діяльності, критичне осмислення, учитель } \\
\text { як перетворюючий інтелектуал. }\end{array}$ \\
\hline
\end{tabular}




\begin{tabular}{|c|c|}
\hline Інтуїція, досвід та ідеї освітніх спільнот. & Науково-емпірична обґрунтованість. \\
\hline $\begin{array}{lcr}\text { Догматизм, } & \text { прескриптивізм } & \text { У } \\
\text { теоретичному } & \text { наповненні } & \text { змісту } \\
\text { підготовки вчителів IM. } & \end{array}$ & $\begin{array}{l}\text { Критичне ставлення до наявних } \\
\text { теоретичних положень. }\end{array}$ \\
\hline Пошук «ідеального» методу навчання IM & Післяметодовий стан, еклектицизм \\
\hline
\end{tabular}

Висновки та перспективи подальших наукових розвідок. Хід розвитку системи фахової підготовки вчителів IM у США визначається сукупністю зовнішніх і внутрішньогалузевих упливів. До кластера безпосередніх чинників належать загальнонаукові й вузькоспеціальні тенденції, які утворюють методологічні підвалини галузі, зокрема філософськоепістемологічні концепції, теоретичні положення предметних галузей загальної та прикладної лінгвістики, лінгводидактики, педагогіки, психології та інших суміжних наук. На підставі узагальнення наукових розвідок американських дослідників виявлено, що ключовими епістемологічними засадами освітньої філософії США, включаючи підготовку вчителів-філологів, $є$ парадигми позитивізму й постпозитивізму, інтерпретивізму, критицизму, у призмі яких розвинулися концепції біхевіоризму, когнітивізму, гуманізму, конструктивізму, соціалконструктивізму, критичної педагогіки й деякі інші.

На сучасному етапі, науково орієнтована світоглядна картина світу американських освітян формується під упливом засадничих положень конструктивізму й соціалконструктивізму, критичної педагогіки, гуманізму та епістемології постпозитивізму. Позитивістська ідеологія, із властивою їй пошуком абсолютних, беззаперечних істин в освітніх процесах поступово здає позиції на користь постпозитивізму, а саме інтерпретивізму та критицизму. Означені підходи характеризуються відмовою від пошуку єдино правильної, ідеальної теоретичної основи в педагогічній дійсності, усвідомлюючи ії контекстуально-ситуативну природу.

У сфері підготовки вчителів IM окреслені тенденції призвели до парадигмальних змін: традиційна трансмісійна або процесуальнопродуктивна освітня модель, сутність якої полягає в озброєнні майбутніх учителів готовим комплектом знань і вмінь, поступово зазнає переосмислення. У розумінні освітньої філософії сьогодення, вчитель $\epsilon$ центральною фігурою, що скеровує процес власного професійного становлення й розвитку, беручи безпосередню участь у формуванні професійної світоглядної позиції, компетентності, відтак ігнорування ролі особистості педагога немислиме. Важливою віхою еволюціонування філософсько-епістемологічних підвалин педагогічної освіти США в соціокультурній перспективі $\epsilon$ врахування комплексного впливу зовнішнього середовища в процесі конструювання індивідом професійних знань, поглядів, переконань. Тобто, компетентність учителя формується за діалектичним принципом, органічно поєднуючи зовнішній інформаційний 
потік і загальний уплив освітніх процесів з індивідуальним досвідом і світоглядною позицією, віддзеркалюючись у соціокультурному контексті. Одним із перспективних напрямів дослідження вважаємо компаративний аналіз концептуальних компонентів американської та вітчизняної систем підготовки вчителів-філологів.

\section{ЛІТЕРАТУРА}

Ball, D., Forzani, F. (2009). The work of teaching and the challenge for teacher education. Journal of Teacher Education, 60 (5), 497-511.

Blazar, D. (2016). Teacher and teaching effects on students' academic performance, attitudes, and behaviors. Doctoral dissertation. Harvard Graduate School of Education.

Britzman, D. (2003). Practice makes practice. A critical study of learning to teach. New York: State University Press.

Brown, D. H. (2000). Principles of language learning and teaching. New York: Longman.

Burns, A. (2013). Innovation through action research and teacher-initiated change. In K. Hyland and L. Wong (Eds.), Innovation and Change in English Language Education (pp. 90-105). Abingdon: Routledge.

Johnson, K. E., Freeman, D. (2001). Teacher learning in second language teacher education: A socially-situated perspective. Revista Brasileira de Linguistica Aplicada, 1(1), 53-69.

Kumaravadivelu, B. (2012). Language teacher education for a global society: A modular model for knowing, analyzing, recognizing, doing, and seeing. New York, NY: Routledge.

Medgyes, P. (2001). When the teacher is a nonnative speaker. In M. Celce-M urcia (Ed.), Teaching English as a second or foreign language, (pp. 415-427). Boston: Heinle \& Heinle.

Philipson, R. (1992). Linguistic imperialism. Oxford: Oxford University Press.

Richards, J., Farrell, T. (2005). Professional development for language teachers: Strategies for teacher learning. Cambridge: Cambridge University Press.

Шихненко, К. (2018). Розвиток лідерського потенціалу вчителів в умовах змін: досвід реформування шкільної освіти в США. Педагогічні науки: теорія, історія, інноваційні технології, 9 (83), 69-79. (Shykhnenko, K. (2018). Developing the leadership potential of teachers under the conditions of educational change: Lessons from school reforms in the USA. Pedagogical Sciences: Theory, History, Innovative Technologies, 9 (83), 69-79).

\section{PEЗЮME}

Левринц Марианна. Трансформация концептуальных положений системы подготовки учителей иностранных языков в США.

Целью статьи является анализ трансформаций концептуальных положений области подготовки учителей иностранных языков в США. Исследование выполнено с применением методов системного анализа и обобщения тенденций развития теоретико-методологических основ сферы иноязычного педагогического образования. Установлено, что в США на передний план педагогического образования выступили концептуальные идеи социалконструктивизма, критической педагогики, гуманизма и эпистемология постпозитивизма, которые оформились в социокультурной парадигме. Основными тенденциями развития методологических основ отрасли является переход от трансмиссионной $к$ колаборативной, транзакционной и преобразовательной моделей высшего образования; от тренировочной к развивающей парадигме подготовки учителей- 
филологов; происходит переосмысление роли студента в процессе учебнопрофессиональной деятельности. Современная концептуальная парадигма характеризуется отказом от идеи прямолинейности в развитии научного знания в пользу переосмысления роли личности в развитии теории, образовательной среды и социокультурного контекста.

Ключевые слова: система подготовки учителей иностранных языков, концептуальные положения, трансрормация, научное знание, США.

\section{SUMMARY}

Levints (Lórinc) Marianna. Transformations in the conceptual orientation of the US system of foreign language teacher education.

The present paper examines transformations of conceptual orientations in the field of foreign language teacher education in the USA. In the study the methods of systematic and retrospective analysis were employed to outline the tendencies in the development of theoretical background of the sphere of language teacher preparation. The foundational theories informing the contemporary academic outlook of American educators are the constructivism, social constructivism, critical pedagogy, humanism, postpositivist epistemology and sociocultural perspective.

One of the main developmental trends in the sphere of language teacher education is characterized by the shift in the instructional models from transmission to collaboration, transaction and transformation. The training approach in teacher preparation is rethought in the perspective of teacher education as development. A discernible shift has taken place in the perception of the role of student-teachers as active transformers of information, who not only consume the relevant theories but also act as co-authors of the professional knowledge base; from being the objects of educational influence and instructional process to its subjects.

One of the general research trends is the focus on the problem of learning to teach as opposed to the previously emphasized teaching students to teach. Recent research also suggests criticism of technicist view in teacher preparation (developing a predefined set of basic knowledge and teaching skills) towards actively engaging future foreign language teachers in the critical evaluation of multiple theoretical perspectives.

In the sphere of language teacher training the prescriptive, dogmatic pursuit of universal educational theory, as well as an ideal foreign language teaching approach are reconsidered in light of pluralism, changeability, epistemic and gnoseological variability. Thus, the contemporary conceptual paradigm of the sphere of language teacher education is characterized by rejection of the idea of straightforwardness in the construction of educational theory in favor of individual, context and culture specific interpretation.

Key words foreign language teacher education system, conceptual orientations, paradigm shift, educational, linguodidactic theory, USA. 